\title{
Effect of Different Growing Seasons of Okra (Abelmoschus esculentus) on Life Cycle Duration and Development of Root-knot Nematode, Meloidogyne javanica
}

\author{
Deepak Kumar*, Anil Kumar and K. K. Verma \\ Department of Nematology, CCS Haryana Agricultural University, Hisar, Haryana, India \\ *Corresponding author
}

\section{A B S T R A C T}

\section{Keywords}

Abelmoschus esculentus, Development, Meloidogyne javanica, Growing seasons, Weather parameters

\section{Article Info}

Accepted: 15 October 2020 Available Online: 10 November 2020
Okra, Abelmoschus esculentus, is being grown from February to July months under varying weather conditions in Haryana, so the present investigation was done to examine the life cycle and development of root-knot nematode (Meloidogyne javanica) in three different growing seasons i.e. spring (March to April), summer (May to June) and monsoon (July to August). These experiments were conducted under screen house conditions of Department of Nematology, CCS Haryana Agricultural University, Hisar. The significant difference was observed in developmental stages and completion of life cycle period of $M$. javanica under different growing seasons. The observations for developmental stages were recorded at initial three days for penetration and after that three days interval for subsequent stages. The penetration of infective juveniles $\left(\mathbf{J}_{2}\right)$ was activated within 24 hours in summer and monsoon season while it started in 72 hours at lower temperature during spring season. Swelling of infective stage $\left(\mathrm{J}_{2}\right)$ of $M$. javanica was started from $3^{\text {rd }}$ days in summer and monsoon seasons while in spring season it was observed on seventh day after inoculation. The spike tail stages i.e. $\mathrm{J}_{3}$ and $\mathrm{J}_{4}$, were observed up to twelve days of inoculation during spring and monsoon seasons while eight days were taken during summer season due to variation in temperature and relative humidity. During spring, summer and monsoon seasons, $M$. javanica completed its one generation in 35,27 and 31 days at average atmospheric temperature of $24.3^{\circ} \mathrm{C}, 33^{\circ} \mathrm{C}$ and $29.5^{\circ} \mathrm{C}$ respectively which occurred during the experiments. Thus, the development and life cycle of $M$. javanica was observed as dependent on weather parameters under same susceptible crop variety which were directly or indirectly correlated with growing seasons.

\section{Introduction}

Okra (Abelmoschus esculentus) is the most important warm season vegetable crop which requires optimum temperature range between 21 to $30^{\circ} \mathrm{C}$ for its proper growth and high yield. It can be grown in wide range of soil and most ideal soil type for okra cultivation is sandy loam to clay loam with rich in organic matter and having better drainage facility. The cultivation of okra crop is very challenging due to attack of various insects- pests and diseases including plant parasitic nematodes (PPNs). Amongst PPNs, root knot nematode (M. incognita and M. javanica) leads to cause extensive damage in okra crop. In 1977, 
Bhatti and Jain recorded the losses due to root-knot nematodes with a tune of 90.9 per cent in okra under Haryana conditions. The losses caused by Meloidogyne spp. to okra crop has been estimated to be about 19.5 per cent which was Rs. 2480.86 million in monetary value (Kumar et al., 2020). Meloidogyne spp. is poikilothermic organism and its development is usually dependent on temperature and moisture content present in soil. Various studies has shown the rates of root-knot nematode embryonic and postembryonic development and life cycle which are strongly affected by weather conditions particularly temperature and vary with the species of Meloidogyne (Strajnar et al., 2011). As the weather conditions are varying during the long growing season of okra, there is every possibility that the development and life cycle of root knot nematode would be altered. Therefore, keeping in view these aspects, the present study was conducted to determine the effect of different growing seasons on the development and life cycle of Meloidogyne javanica in okra.

\section{Materials and Methods}

The present study was conducted under screen house conditions to study the development and life cycle of $M$. javanica during different growing seasons i.e. spring (March to April), summer (May to June) and monsoon (July to August) of okra crop. The sandy loam soil used in the experiment was sterilized by autoclaving at $121^{\circ} \mathrm{C}$ and $15 \mathrm{lbs}$ pressure for 20 minutes and filled in one kilogram soil capacity earthen pots. Seeds of okra cv. Hisar Unnat (a nematode susceptible variety) were sown in these pots and at two leaves stage, single plant per pot was maintained by thinning out the extra plants. Fertilization of okra plants was done with the recommended dose of fertilizers. Ten days old plants were inoculated with 400 freshly hatched $\mathrm{J}_{2}$ per pot of $M$. javanica. The observations were recorded on time taken for penetration, time taken to complete different developmental stages i.e. $\mathrm{J}_{2}$ to $\mathrm{J}_{3}, \mathrm{~J}_{3}$ to $\mathrm{J}_{4}, \mathrm{~J}_{4}$ to adults and eggmass production and time taken for completion of complete life cycle $\left(\mathrm{J}_{2}\right.$ to $\mathbf{J}_{2}$ ). These observations were recorded regularly up to initial three days for penetration of juveniles and after that further observations were recorded at each next three days interval after staining the roots in $0.1 \%$ acid fuchsin lactophenol. The stained roots were observed under stereoscopic binocular microscope by teasing out the different developmental stages. The same process and set of experiment was repeated during all three growing seasons.

\section{Results and Discussion}

The current study showed the direct effects of growing seasons on the various developmental stages and complete life cycle of $M$. javanica. The prevailed temperature $\left({ }^{\circ} \mathrm{C}\right)$ and relative humidity (\%) during every growing season alters the time period taken by each developmental stage which ultimately leads to change in complete life cycle period.

The results presented in Table 1 of spring season crop revealed that the infective stage $\left(\mathrm{J}_{2}\right)$ of $M$. javanica penetrated into young roots of okra on $3^{\text {rd }}$ day of inoculation. However, swollen $\mathbf{J}_{2}$ and the swelling on the infected roots was observed on $7^{\text {th }}$ day after inoculation (DAI). On $11^{\text {th }}$ DAI, $\mathrm{J}_{2}$ that had infected the roots started to develop into spike tailed third stage juveniles $\left(\mathrm{J}_{3}\right)$ and the swellings were converted into easily visible galls on the infected roots. The $\mathrm{J}_{3}$ was developed into spike tailed $\mathrm{J}_{4}$ stage on $19^{\text {th }}$ DAI with medium sized galls on roots and it lasted up to $23^{\text {rd }}$ DAI. The premature females and few of the males were observed on $27^{\text {th }}$ DAI. Mature females with eggmass deposition on the galls were seen on $31^{\text {st }}$ DAI. After hatching of newly formed eggmasses, $\mathbf{J}_{2}$ 
were detected inside the roots with new swellings as well as few penetrated into old galls also on $35^{\text {th }}$ DAI. Thus, the whole life cycle of $M$. javanica in okra crop during spring season had been completed in 35 days $\left(J_{2}\right.$ to $J_{2}$ stage) at temperature range between 15.4 to $33.2^{\circ} \mathrm{C}$, relative humidity range from 34.0 to 69.7 per cent and average rainfall 14.0 $\mathrm{mm}$ (from sowing of crop to 35 days after inoculation). The meteorological data such as rainfall was recorded on daily basis but this data is depicted in tables only for those days on which observations were taken on life cycle and development. The data showed in Table 2 of summer season concluded that the whole life cycle of $M$. javanica in okra during summer season had been completed in 27 days ( $\mathrm{J}_{2}$ to $\mathrm{J}_{2}$ stage) at temperature range between 25.2 to $40.7^{\circ} \mathrm{C}$, relative humidity from 39.0 to 67.2 per cent and average rainfall $2.2 \mathrm{~mm}$ (from sowing of crop to 27 days after inoculation). The infective $\mathrm{J}_{2}$ of $M$. javanica penetrated into young roots of okra within initial $48 \mathrm{hrs}$ of nematode inoculation with maximum penetration on $2^{\text {nd }}$ days of inoculation. However, swollen $\mathrm{J}_{2}$ and the swelling on the infected roots was observed on $3^{\text {rd }}$ DAI. On $7^{\text {th }}$ DAI, $\mathrm{J}_{2}$ that had infected the roots started to develop into $\mathrm{J}_{3}$ stage and the swellings were converted into easily visible galls on the infected roots. The $\mathrm{J}_{3}$ stage was developed into spike tailed $\mathrm{J}_{4}$ on $15^{\text {th }}$ DAI with medium sized galls on roots. On $19^{\text {th }}$ DAI, all the $\mathrm{J}_{4}$ were developed into premature females and some male stages were also seen. Mature females with eggmass deposition on the galls were observed on $23^{\text {rd }}$ DAI and after 3 days few of the $J_{2}$ were started to form new swellings on the roots as well as few were observed to be penetrated into old galls also. Likewise the whole life cycle was completed in 27 days in summer season.

Table.1 Time taken for life cycle completion and development of Meloidogyne javanica in okra during spring season

\begin{tabular}{|c|c|c|c|c|c|c|c|}
\hline \multirow{2}{*}{$\begin{array}{l}\text { Observations } \\
\text { (Days after } \\
\text { inoculation) }\end{array}$} & \multirow{2}{*}{$\begin{array}{c}\text { Developmental } \\
\text { stages of } \\
\text { nematode }\end{array}$} & \multirow[t]{2}{*}{ Remarks } & \multicolumn{2}{|c|}{$\begin{array}{c}\text { Temperature } \\
\left({ }^{\circ} \mathrm{C}\right)\end{array}$} & \multicolumn{2}{|c|}{$\begin{array}{c}\text { Relative Humidity } \\
(\%)\end{array}$} & \multirow[t]{2}{*}{$\begin{array}{c}\text { Rainfall } \\
\text { (mm) }\end{array}$} \\
\hline & & & Max. & Min. & Morning & Evening & \\
\hline 1 & $\mathrm{~J}_{2}$ & No penetration & 29.4 & 13.0 & 80 & 31 & 0.0 \\
\hline 2 & $\mathbf{J}_{2}$ & -do- & 29.8 & 9.0 & 78 & 30 & 0.0 \\
\hline 3 & $\mathrm{~J}_{2}$ & Penetration started & 31.4 & 11.7 & 81 & 32 & 0.0 \\
\hline 7 & Swollen $\mathbf{J}_{2}$ & Swelling started & 27.4 & 10.5 & 84 & 51 & 0.0 \\
\hline 11 & $\mathrm{~J}_{3}$ & $\begin{array}{l}\text { Spike tailed stage } \\
\text { and easily visible } \\
\text { galls }\end{array}$ & 34.4 & 12.0 & 77 & 22 & 0.0 \\
\hline 15 & $\mathrm{~J}_{3}$ & -do- & 35.2 & 13.7 & 72 & 40 & 0.0 \\
\hline 19 & $\mathrm{~J}_{4}$ & $\begin{array}{l}\text { Spike tailed stage } \\
\text { and medium sized } \\
\text { galls }\end{array}$ & 37.0 & 18.5 & 58 & 28 & 0.0 \\
\hline 23 & $\mathrm{~J}_{4}$ & -do- & 35.0 & 21.4 & 64 & 35 & 0.0 \\
\hline 27 & $\begin{array}{l}\text { Premature } \\
\text { female }\end{array}$ & Large sized galls & 28.4 & 15.2 & 80 & 40 & 2.2 \\
\hline 31 & $\begin{array}{l}\text { Female with } \\
\text { Eggmasses }\end{array}$ & Eggmasses on galls & 38.1 & 21.8 & 51 & 29 & 0.0 \\
\hline 35 & $\mathrm{~J}_{2}$ & $\begin{array}{c}\text { New swelling } \\
\text { started }\end{array}$ & 39.0 & 23.0 & 42 & 36 & 0.0 \\
\hline
\end{tabular}


Table.2 Time taken by life cycle and development of Meloidogyne javanica in okra during summer season

\begin{tabular}{|c|c|c|c|c|c|c|c|}
\hline \multirow{2}{*}{$\begin{array}{c}\text { Observations } \\
\text { (Days after } \\
\text { inoculation) }\end{array}$} & \multirow{2}{*}{$\begin{array}{c}\text { Developmental } \\
\text { stages of } \\
\text { nematode }\end{array}$} & \multirow[t]{2}{*}{ Remarks } & \multicolumn{2}{|c|}{$\begin{array}{c}\text { Temperature } \\
\left({ }^{0} \mathrm{C}\right)\end{array}$} & \multicolumn{2}{|c|}{$\begin{array}{c}\text { Relative Humidity } \\
(\%)\end{array}$} & \multirow[t]{2}{*}{$\begin{array}{c}\text { Rainfall } \\
\text { (mm) }\end{array}$} \\
\hline & & & Max. & Min. & Morning & Evening & \\
\hline 1 & $\mathrm{~J}_{2}$ & Penetration started & 38.6 & 20.9 & 63 & 45 & 0.0 \\
\hline 2 & $\mathrm{~J}_{2}$ & -do- & 38.9 & 23.5 & 68 & 44 & 0.0 \\
\hline 3 & Swollen $\mathbf{J}_{2}$ & Swelling started & 40.8 & 25.0 & 61 & 39 & 0.0 \\
\hline 7 & $\mathrm{~J}_{3}$ & $\begin{array}{l}\text { Spike tailed stage and } \\
\text { easily visible galls }\end{array}$ & 41.7 & 23.0 & 60 & 36 & 0.0 \\
\hline 11 & $\mathrm{~J}_{3}$ & -do- & 43.2 & 22.9 & 44 & 22 & 0.0 \\
\hline 15 & $\mathrm{~J}_{4}$ & $\begin{array}{l}\text { Spike tailed stage and } \\
\text { medium sized galls }\end{array}$ & 45.6 & 29.3 & 72 & 36 & 0.0 \\
\hline 19 & $\begin{array}{l}\text { Premature } \\
\text { female }\end{array}$ & Large sized galls & 41.9 & 27.3 & 84 & 42 & 0.0 \\
\hline 23 & $\begin{array}{l}\text { Females with } \\
\text { Egg masses }\end{array}$ & Egg masses on galls & 38.4 & 28.0 & 79 & 42 & 0.0 \\
\hline 27 & $\mathrm{~J}_{2}$ & New swelling started & 37.0 & 27.0 & 74 & 45 & 0.0 \\
\hline
\end{tabular}

Table.3 Time taken for life cycle and development of Meloidogyne javanica in okra during monsoon season

\begin{tabular}{|c|c|c|c|c|c|c|c|}
\hline \multirow{2}{*}{$\begin{array}{c}\text { Observation } \\
\text { (Days after } \\
\text { inoculation) }\end{array}$} & \multirow[t]{2}{*}{$\begin{array}{l}\text { Developmental } \\
\text { stages }\end{array}$} & \multirow[t]{2}{*}{ Remarks } & \multicolumn{2}{|c|}{$\begin{array}{c}\text { Temperature } \\
\left({ }^{0} \mathrm{C}\right)\end{array}$} & \multicolumn{2}{|c|}{$\begin{array}{c}\text { Relative Humidity } \\
(\%)\end{array}$} & \multirow[t]{2}{*}{$\begin{array}{c}\text { Rainfall } \\
\text { (mm) }\end{array}$} \\
\hline & & & Max. & Min. & Morning & Evening & \\
\hline 1 & $\mathrm{~J}_{2}$ & Penetration started & 35.2 & 25.5 & 100 & 84 & 1.1 \\
\hline 2 & $\mathrm{~J}_{2}$ & -do- & 32.4 & 26.0 & 90 & 89 & 1.1 \\
\hline 3 & Swollen $\mathbf{J}_{2}$ & Swelling started & 31.1 & 26.5 & 92 & 70 & 0.0 \\
\hline 7 & $\mathbf{J}_{3}$ & $\begin{array}{l}\text { Spike tailed stage and easily } \\
\text { visible galls }\end{array}$ & 30.8 & 25.5 & 100 & 73 & 43.1 \\
\hline 11 & $\mathrm{~J}_{3}$ & -do- & 31.4 & 26.9 & 91 & 75 & 0.8 \\
\hline 15 & $\mathrm{~J}_{4}$ & $\begin{array}{l}\text { Spike tailed stage and medium } \\
\text { sized galls }\end{array}$ & 35.6 & 26.6 & 78 & 55 & 0.0 \\
\hline 19 & $\mathrm{~J}_{4}$ & -do- & 36.9 & 27.0 & 76 & 56 & 0.0 \\
\hline 23 & $\begin{array}{c}\text { Premature } \\
\text { females }\end{array}$ & Large sized galls & 28.2 & 25.2 & 97 & 100 & 0.0 \\
\hline 27 & $\begin{array}{c}\text { Females with Egg } \\
\text { masses }\end{array}$ & Egg masses on galls & 37.0 & 27.0 & 85 & 63 & 0.0 \\
\hline 31 & $\mathrm{~J}_{2}$ & New swelling started & 34.6 & 27.5 & 94 & 66 & 0.0 \\
\hline
\end{tabular}


Fig.1 Comparison of development and life cycle of Meloidogyne javanica under different growing seasons (spring, summer and monsoon) of okra

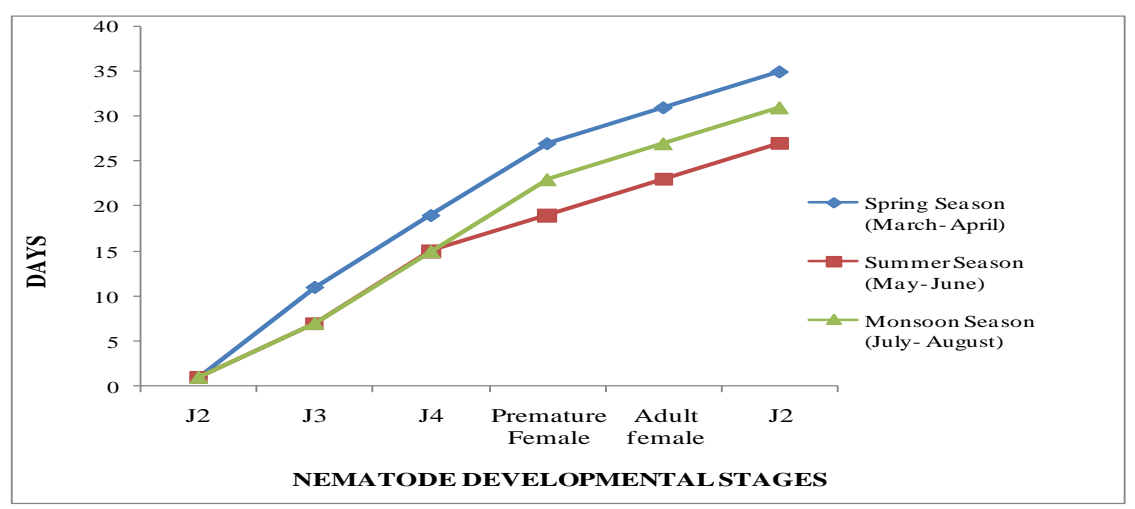

The data of monsoon season presented in Table 3 showed that the completion of life cycle of $M$. javanica in okra during monsoon season in 31 days ( $J_{2}$ to $J_{2}$ stage) with temperature range between 26.4 to $33.3^{\circ} \mathrm{C}$, relative humidity between 73.1 to 90.3 per cent and average rainfall $142.1 \mathrm{~mm}$ (from sowing of crop to 31 days after inoculation). During this season, the nematode started penetration within initial $48 \mathrm{hrs}$ of inoculation into young roots of okra. So, from the next day, there had been seen slight swelling on the infected roots along with swollen $\mathrm{J}_{2}$. On seventh days after inoculation, $\mathrm{J}_{2}$ that had infected the roots started to convert into spike tailed $\mathrm{J}_{3}$ and along with easily visible galls on the infected roots. Up to one week, the spike tailed $\mathrm{J}_{3}$ was prevailed in the infected roots with medium sized galls. On $15^{\text {th }}$ DAI, all $\mathrm{J}_{3}$ was started to convert into $\mathrm{J}_{4}$ stage. All the $\mathrm{J}_{4}$ were developed into premature females and few of the males were also detected on $23^{\text {rd }}$ DAI. After 3 days, adult females with eggmass deposition on the galls were observed. Few newly hatched $\mathbf{J}_{2}$ were also detected inside the roots with new swellings while some of juveniles were observed inserted inside the old galls also on $31^{\text {th }}$ DAI. Hence, the total life cycle of $M$. javanica had been observed to complete in 31 days during monsoon season. Here Fig. 1 represents the comparison between the life cycle of $M$. javanica completed during all the three growing seasons in okra.

The $\mathbf{J}_{2}$ penetrated into young roots of okra seedling near the root tip within $24 \mathrm{hrs}$ in summer and monsoon season while in spring season, the penetration was recorded in 72 hrs. Swollen $J_{2}$ stage was found on $3^{\text {rd }}$ DAI in summer and monsoon season but it took seven days in spring season. After penetration, $\mathrm{J}_{2}$ moulted into $\mathrm{J}_{3}$ on $7^{\text {th }}$ day in summer and monsoon season while in spring season it was observed on $11^{\text {th }}$ day. $\mathrm{J}_{3}$ stage further developed into $\mathrm{J}_{4}$ in 15 DAI in summer and monsoon season while in spring season it has taken 19 days. Premature female was observed on 19 DAI during summer season, 23 DAI in monsoon season and 27 DAI in spring season. Mature female with eggmass deposition was observed in 23 DAI in summer season, 27 DAI in monsoon season and 31 DAI in spring season. Freshly hatched $\mathrm{J}_{2}$ were found in soil as well as penetrated inside the roots in 27 DAI in summer season, 31 DAI in monsoon season and 35 DAI in spring season. In spring season, the life cycle was completed in 35 days at average temperature range between 15 to $33^{\circ} \mathrm{C}$ and average relative humidity 34 to 70 per cent. In summer season, the life cycle of $M$. javanica was completed in 27 days at average temperature range between 25 to $41^{\circ} \mathrm{C}$ and 
relative humidity 39 to 67 per cent. In monsoon season, the time taken by completion of one life cycle was 31 days at average temperature range between 26 to $33^{\circ} \mathrm{C}$ and average relative humidity 73 to 90 per cent. Kumar et al., 2016 explained that differences in time taken by the nematode to complete its one generation must be due to different weather conditions such as temperature, relative humidity, rainfall and many other factors. Khan et al., (2010) concluded that 27 days were required by $M$. javanica to complete its one life cycle in broccoli at thermal range of 28 to $35^{\circ} \mathrm{C}$ while the variation in life cycle in present study was only due to different weather condition prevailed during every growing season. The results of present study are in conformity with the results of Kumari et al., (2018) who has also observed that the $M$. incognita completed its life cycle early in summer as compared to spring season and in partial conformity with the results of Anamika and Simon (2012) who observed that inoculated seedlings raised (tomato and brinjal) during the month of June showed delayed $\mathrm{J}_{2}$ penetration of $M$. incognita and there was too early completion of nematode life cycle.

In present study, the differences in time taken for penetration of nematode depended on different growing seasons specially prevailed temperature, relative humidity and rainfall. In summer season, the life cycle was completed in lesser time period (27 days) as compared to other seasons due to higher temperature during May to June under Haryana conditions. It was clearly the effect of temperature on the rate of penetration of larvae into the plant. At higher temperature, the metabolic reactions of the nematode became faster as compared to normal temperature conditions so that the nematode completed its developmental stages sooner. Similar findings were also reported by Negron and Dickson (2013), who observed that temperature influenced the ontology of Meloidogyne javanica and other species. Zinoviev in the year 1957 observed the higher temperatures not only increased the physical activity of the nematode but in thermophilic genera such as Meloidogyne spp., they also increased the secretion of the extra oral digestive enzymes which assisted in penetration. In present studies, as temperature decreased, the life cycle of $M$. javanica prolonged eight and four days during spring and monsoon season respectively as compared to summer season. For $M$. javanica, the number of days required to complete its developmental stages were directly influenced by temperature and relative humidity. The results are in conformity with the results of Negron and Dickson (2013) who found that 34 days required to complete life cycle of $M$. javanica at a mean temperature of $21^{\circ} \mathrm{C}$, compared with 50 days at $18^{\circ} \mathrm{C}$ in okra. As nematodes are hydrophilic in nature so they require a thin film of water around soil particles for its better migration and survival. In present study, the development and life cycle of the nematode was observed faster during monsoon as compared to spring season. It was due to occurring of more rainfall during monsoon season which resulted into high relative humidity as well as soil moisture content that were observed favorable for the nematode development and it is in conformity with the results of Simons (1973).

\section{Acknowledgement}

We are very thankful to Department of Agricultural Meteorology, CCSHAU, Hisar for providing us daily data on weather parameters.

\section{References}

Anamika and Simon, S. 2012. Variation in life cycle of Meloidogyne incognita in 
different months in Indian condition. International Journal of Science and Research. 3(7): 2286-2288.

Bhatti, D.S. and Jain, R.K. 1977. Estimation of loss in okra, tomato and brinjal yield due to Meloidogyne incognita. Indian Journal of Nematology. 7(1): 37-41.

Khan, T.A., Ashraf, M.S. and Dar, R.A. 2010. Pathogenicity and life cycle of Meloidogyne javanica on broccoli. Archives of Phytopathology and Plant Protection. 43(6): 602-608.

Kumar K, Sharma MK, Chandrawat BS, Srivastava AS and Thagaria G (2016) Studies on life cycle of root-knot nematode, Meloidogyne incognita on funnel (Foeniculum vulgare Mill.). Current Nematology. 27(1): 39-43.

Kumar, V., Khan, M.R. and Walia, R.K. 2020. Crop loss estimation due to plant parasitic nematodes in major crops in India. National Academics Science Letter.

Kumari, B., Kanwar, R.S. and Kumar, V. 2018. Effect of different temperature on the life cycle of root-knot nematode, Meloidogyne incognita in okra. Journal of Entomology and Zoology Studies. 6(6): 1160-1162.

Negron, M.D. and Dickson, D.W. 2013. Comparative thermal-time requirements for development of Meloidogyne arenaria, M. incognita and $M$. javanica at constant temperatures. Nematropica. 43:152163.

Simons, W.R. 1973. Nematode survival in relation to soil moisture. Mededelingen Landbouwhogeschool Wageningen. 73(3):1-85.

Strajnar, P., Sirca, S., Knapic, M. and Urek, G. 2011. Effect of Slovenian climatic conditions on the development and survival of the root-knot nematode Meloidogyne ethiopica. European Journal of Plant pathology. 129(1): 8188.

Zinoviev, V.G. 1957. Enzymatic activity of nematodes parasitizing plants. Zoologicheskii Zhurnal. 36: 617-620 (Russian).

\section{How to cite this article:}

Deepak Kumar, Anil Kumar and Verma, K. K. 2020. Effect of Different Growing Seasons of Okra (Abelmoschus esculentus) on Life Cycle Duration and Development of Root-knot Nematode, Meloidogyne javanica. Int.J.Curr.Microbiol.App.Sci. 9(11): 2290-2296. doi: https://doi.org/10.20546/ijcmas.2020.911.274 